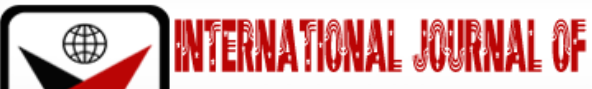

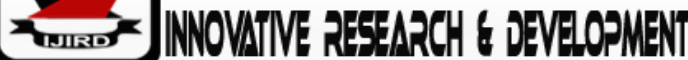

ISSN 2278-0211 (Online)

\section{Early Years Education and Duties within the Oromo Gada System (OGs): Implications for Later Life Experiences}

\author{
Dr. Firdissa Jebessa Aga
}

Associate Professor, Institute of Educational Research, Addis Ababa University, Ethiopia

\begin{abstract}
:
The purpose of this study was to investigate early years' education and duties (portraying economic, social, cultural and political roles) within the context of the Oromo Gada System (GS) and derive implications for later life experiences of the children. The study employed qualitative approach. Data were collected by reviewing literatures, by conducting interviews, and making visits to places where children practice modeling desirable deeds and opposing undesirable ones. The results have shown that children with in the GS get matured with desirable moralities endowed with the Oromo concept of reality, and desirable values and principles. There, however, are concerns calling attention to make reforms regarding females' roles and fitting children into the dynamism of the 21st century world of life and work environments.
\end{abstract}

Keywords: Early years Children, Education, Oromo, Gada System, Life experiences

\section{Introductory and Conceptual Background}

The Oromo are indigenous African people inhabiting the North Eastern part of Africa. They are the single most dominant largest Cushitic speaking people occupying a huge land area and constituting 45\% of the Ethiopian population (Baxter, Jan \& Alessandro, 1996; Hassen, 1990, 1996; Legesse, 1973; Baxter, 1994; Tareke, 1991; Hussein, 2004).

The Oromo people's home land, known as, Oromia is approximately located between 3- and 15-degrees north latitude and 33- and 40-degrees longitude. Oromia is 375,000 square miles or 600,000 square kilometers. The Oromo speak Afaan Oromo, which is a Cushitic language spoken by more than 50 million people in Ethiopia, Kenya, Somalia, Egypt, United States, Australia, Canada and different European cities. Afaan Oromo, which has the status of an official language in Oromia, is the 3rd largest language in Africa, after Arabic and Hausa. Systemically, culturally as well as religiously, the Oromo people manner their children in Waaqeffanna (the traditional belief in Waaqaa or God), Islam, and Christianity (Orthodox, Catholic and Protestant) (Baxter, Jan \& Alessandro, 1996; Bulcha, 1996; Bokkuu, 2009).

The Oromo are with their own distinctive history, customs, beliefs, and values. Inasmuch as over $85 \%$ of the Oromo people make a living by farming, they grow up their children for their early economic roles and for their later lives. Though the practices are being changed following the wide acceptance of Western Modern education, basically the Oromo expose their children to indigenous type of early childhood education which is very different from that of the Western industrialized societies. Before joining formal education of the western type, boys and girls in Oromia are prepared to take up economic and cultural roles and responsibilities within an indigenous form of governance called Gada System (GS). The important learning goals for Oromo children, beyond economic and cultural roles, are to understand ancestry and genealogical lines, religion, moral and ethical behavior.

As Jaarraa and Saaddoo (2011:49) indicate, parents have obligations to train their offspring through riddles, storytelling, etc. They teach how people with good deeds become respected and those with wrecked deeds degraded. Children, both boys and girls, are expected to grow with good behavior, to be honest, to respect elders including father and mother, neighborhood, adopted other children, clan acceptable character, open-minded, and optimistic personalities. Children are cultured to these desirable personalities through proverbs, riddles, stories, and through taking part in celebrations and ceremonies that allow them to rehearse the roles they are living and will take on later as adults. The emphasis is on co-operation, family and community involvement, and a strong sense of right and wrong which grows out of their religious understanding of the connectedness between people and nature. Such an early education provides a sharp contrast to the academic and highly competitive approach found in contemporary Western societies.

Though there are variations from place to place, boys and girls receive equal care, treatment, and equal opportunities during the early years (ages 0-8). Knowledge about the GS is transmitted to children at home and at schools. At a very early stage, the Oromo boys and girls engage in cognitive self-categorization (Hallpike, 1976). This is later enhanced by other intensive process of socialization in the society. As a result, children of both sexes are cultured in proper moral conduct, social cohesion, and expressing forms of community culture, inclusiveness, accommodativeness, cooperation, and respect. 
As children grow up, nonetheless, boys and girls are treated differently. The degree of differentiation of roles between the sexes increases with age. Activities and social roles are formally defined separately for boys and girls, both in terms of what is permitted and in terms of what is forbidden. Whereas boys are prepared for leadership roles through competition, girls are prepared for consultative role models. In extreme cases, compounded with intrusions from others' cultures other than the Oromo, the practices lead to strangely muffling women's voices.

For instance, boys become members of classes/parties and start learning and obeying certain duties and roles. Equally, girls observe women's consultative roles on all matters and decisions including their rights. The teachings take different forms starting informally at home. Later on, nonetheless, learning takes place in non-formal arrangements in the form of ritual ceremonies and meetings, which take place under a sycamore tree (considered the Gada symbol) and recently at schools (Hussein, 2004; Hallpike, 1976; Bokkuu, 2009)

Whereas the GS had been under threat by the successive Ethiopian regimes for over a century, it has beenrevitalized and -inscribed on UNESCO's Representative List as Intangible Cultural Heritage of Humanity as of November 30, 2016. The inscription event took place in Ethiopia from 28 November to 04 December 2016 when Ethiopia hosted the 11th session of UNESCO's Intergovernmental Committee (representatives of 24 State Parties) for the Safeguarding of Intangible Cultural Heritage. The event and the case demonstrate to the rest of the world that the country is not only the cradle of mankind but also the mother of an age-old egalitarian democratic system (ORCTB, 2015). The declaration of the Oromo people's traditional, socio-political governance system ('Gada') as UNESCO Intangible Cultural Heritage could attract much-needed international attention and help raise awareness of the Oromo's plight for years.

\subsection{Features of the Oromo GS}

The Oromo GS is a n indigenousdemocratic, egalitarian, powerful constitutional form of governance; and an age graded system combined with sophisticated and extremely efficient socio-economic and political system (ArdaaJilaa, 2009; ORCTB, 2015). It has been shaping and guiding the lives, governance, and philosophical outlooks of the Oromo. It is also known for ensuring unity and solidarity among people, and for resolving conflicts peacefully and amicably. It is based upon the principles of equality among mankind-regardless of age, sex, ethnicity, and religious affiliations. Under the System, the power to administer the affairs of the nation and the power to make laws belong to the people who share different responsibilities to ensure check and balance. All the people have the right to air their views in any public gathering without fear. OGS has immense amount of influence on Oromo society up to date.

The OGS is a result of many years of practices, experiences of self-governance and knowledge gained by community over generations. After long years of informal practices, it was formally established in the $14^{\text {th }}$ century under the rule of Gadaayo Galgalo Yayyaa (Ardaajilaa, 2009; Bokkuu, 2009). Based on the information obtained from Arero Ramadan, Jaarraa and Saaddoo (2011) have indicated that the OGS had been the governance of the Orom for over 4000 years. Whereas formerly the Oromos have been under one rule for over 25 Abba Gadaas after Gadaa was instituted, the Borana Oromo have already 72 Aba Gadas up to now. This shows that the Borana Oromo has over 576 years of indigenous democratic and egalitarian governance system. Despite unprecedented challenges they encountered, the BoranaOromo maintained this sophisticated and extremely efficient system as it was instituted by founding fathers up-to-date (Jaarraa\&Saaddoo, and Dirrib, 2009).

The OGS has five classes/parties (commonly called Luba or gogessa for Borana); and ten/eleven sequential grades.As ArdaaJilaa (2009) indicates, the five groups/parties/classes or luba (gogessa) are recruited on the basis of genealogical generations. Luba can be defined as a segment of a generation that assumes power for a period of eight years, whereas Gadaa is the years when the members of the class stay in power as rulers. The names of the Gada classes vary from place to place. Based on the data from Bokkuu (2009) and Jaarraa and Saaddoo (2011), the five classes/parties are presented in Table 1 below.

\begin{tabular}{|c|c|c|c|c|c|}
\hline & s' Gadaa & Children's Gadaa & \multirow{6}{*}{ Vis-à-vis } & Fatehrs' Gadaa & Children's Gadaa \\
\hline 1. & Meelbaa & Harmufa & & Birmaji & Aldaada \\
\hline 2. & Muudana & Roobalee & & Malba & Horata \\
\hline 3. & Kiilolee & Birmajii & & Muudana & Biifolee \\
\hline 4. & Biifolee & Mul'ataa & & Roobale & Sabbaaqa \\
\hline 5. & Michille & Jabanaa & & Dullo & Kiilolee \\
\hline
\end{tabular}

Table 1: Gada Classess for Fathers and Children

Source: Bokkuu (2009:261, 413,456) Vis-à-visJaarraa \& Saaddoo (2011:61)

Various socio-political functions and responsibilities are associated with each class/party. Each Gada class remains in power during a specific term (Gada) for eight years, which begins and ends with a formal power transfer ceremony governed by established principles of rule of law. The principles are consciously inculcated to- and are inherent within- the ten/eleven sequential grades (see Table 2 below) that occur in eight years interval and correlate with chronological ages beginning at birth. Particularly, boys in the first grade are the sons of men in the 6th grade; in the 2nd grade, of men in the 7 th grade, and so on.

Each class progresses through a series of grades before it can function in authority with the leadership changing on a rotational basis every eight years. Class membership is open to men, whose fathers are already members, while women have consultative roles on all matters and decisions including their rights. The classes are taught by oral historians 
covering history, laws, rituals, time reckoning, cosmology, myths, rules of conduct, and the function of the OGS (Hussein, 2004; Hallpike, 1976; Bokkuu, 2009).

\begin{tabular}{|c|c|c|c|}
\hline Grades & Aga & Grades & Features \\
\hline 1 & $1-8$ & Dabballe & the grade of the uninitiated boys \\
\hline 2 & $9-16$ & Ittimako & Mixing with others \\
\hline 3 & $17-24$ & Foollee & readiness for responsibilities \\
\hline 4 & $25-32$ & Qondaala & junior warriors \\
\hline 5 & $33-40$ & RaabaDori & senior warriors \\
\hline 6 & $41-48$ & Gadaa & the stage of political and ritual leadership \\
\hline 7 & $49-56$ & Yuuba 1ffaa & stage of partial retirement \\
\hline 8 & $57-64$ & Yuuba 2ffaa & stage of partial retirement \\
\hline 9 & $65-72$ & Yuuba 3ffaa & stage of partial retirement \\
\hline 10 & $73-80$ & [Yuuba 4ffaa] $^{1}$ & stage of partial retirement \\
\hline \multirow[t]{2}{*}{11} & $80-88$ & Gadamoojjii & the terminal sacred grade \\
\hline & After 88 & Jaarsa & at which care \& support is rendered \\
\hline
\end{tabular}

Table 2: Gada Grade Names, Ages and Feature

The lowest Gada grade, Dabale (age 0-8), lays foundations. At this level boys and girls have similar roles and are exposed to their early economic and cultural roles and general enlightenment in Ormomumma (Oromoness). At ages 9-16, nonetheless, the children are engaged in exercising their future roles, which are different for boys and girls, engagements in in herding, opposing undesirable deeds, and modeling desirable ones. In most cases, girls engage in fetching firewood and water. The age from 17-24 passes children to more differentiated responsibilities including engaging boys in security and intelligence, and eventfully prepares them for the next age range 25-32 at which they learn the art of governance, leading married life, and majorly engage in defense responsibility.

At the age range from 33-40, the Gada children are expected to have sons and could start procreating so as to acquire the aspired and respected status of fatherhood and motherhood. This stage is when men plan to take power by virtue of the gained arts of leadership and philosophy, and females prepare for consultative roles. The Gada age (41-48) is the stage of full political maturity whereby men from the five classes compete to be the ruling party for eight years. This is the peak of social and political career of Gada and the optimum age of having the required knowledge, skills and attitude of holding and practically showing societal responsibilities.

The end of the Gada age gives rise to Yuba, age 49 and above at which the Gada retires and becomes a Yuba elder. The most important responsibility of retired Gada class (Yubaa) is to oversee the ceremonial activities of the luba in power, and also to engage in advisory roles and act as mediator, ritual experts and peacemakers. The last is Gadaammojjithe stage at which one retires from responsibilities, followed by Jarsaaafter 88 years of age (ORCTB, 2017; ArdaaJilaa, 2009; Hallpike, 1976; Legesse, 2001, 1973).

The OGS has a distinct distribution of political, military, judicial, legislative and ritual responsibilities and authorities among its members within the classes and grades of genealogical generations that succeed each other every eight years. The well-known Gada officials include:

- AbbaaBokkuu (carrier of the scepter/scraper holding a position similar to that of a magistrate), elected from senior clan to bless and preside over the Caffee (assembly) and proclaims the laws. He is the head equivalent of president in modern governments.

- Aba Gadaaa (operational leader),

- AbbaaCaffee (father of legislative assembly),

- AbbaaAlangee (attorney general),

- AbbaaSa'aa (ministry of economy/finance),

- AbbaaSeeraa (a parliamentarian),

- AbbaaDuulaa (war leader or defense minister) who directs the army, and

- A council known as shanee or salgee and retired Gada officials also help the Abba Boku to run the government.

The main election qualifications include virtues, ability, bravery, knowledge, honesty, and courage- ensured in rigorous practical or actual testing of the candidates before they assume office. The System has established a political philosophy underpinned by the principles of checks and balances (through periodic succession of every eight years), and division of power (among executive, legislative, and judicial branches), balanced opposition (among five parties), and power sharing between higher and lower administrative organs to prevent power from falling into the hands of despots. These checks and balances are created to prevent misuse of power. Corrupt or dictatorial leaders would be removed from power through buqisu (recall) before the official end of their term. This practice exists in countries like USA whereby there is a room to oust a president after four years of terms of office depending on his/her achievements.

Other principles of the system include balanced representation of all clans, lineages, regions and confederacies, accountability of leaders, the settlement of disputes through reconciliation, and the respect for basic rights and liberties. When one passes from one grade to the other, his roles and responsibilities in the community also changes, in such a way, an individual or group of individuals who are assuming the office will be critically tested. In the system, the Oromo women 
have a parallel institution known as siqqee through which gender equality is ensured (Legesse, 2001; Baxter, Hulina, \&Triulzi, 1996).

Overall, the OGS has the role of regulating political stability, economic development, social cohesions, cultural obligations, democratic system, moral and ritual responsibilities, the philosophical and religious order of the society, military purposes, conflict resolution, arbitrations and reparations, respecting human rights, environmental conservations, peaceful co-existence, ending of hostilities, prayer to 'Waaqaa', cleansing of sin, adoption, sustaining the cultural assets such as Irreechaa ceremony, an effective system of 'checks and balances', nonexistence of totalitarianism and abuse of power (ORCTB, 2015; Hallpike, 1976).

\subsection{Problem Statement}

As indicated earlier, the Oromo GS had been under threat by the successive Ethiopian regimes. This in turn has resulted in socio-political, cultural and moral imbalances including uncertainties regarding the duties (portraying socioeconomic, cultural and political roles) that are associated to the different genealogical lines within the system. This, in the early years of education and the inherent duties, may have positive or negative repercussions on the children's later life experiences. The uncertainties are sustained due to the Ethiopian imbalance politics down the successive regimes that engaged on homogenization and assimilation of the nations and nationalities with the pretext of nation building. Early years children are not exceptional for the homogenization and assimilation endeavors. It has, therefore, become blurred to precisely tell the duties that are associated to the early yeas children's life within the Oromo GS. Different sources also present differently the roles that the Oromo GS assigns to the sexes and consequently, it has become difficult to gauge the positive and/or negative effects that the roles within the System have on later life experiences of the children.

The uncertainties have been exacerbated by the intrusion of the modern age into all walks of life whereby the Oromo children cannot be exceptional. Consequently, it is high time to investigate the case and come up with viable child care practices within the Oromo GS and derive implications for future directions and actions pertaining to early years of child care and education in Oromia.

\subsection{Objectives of the Study}

The overall purpose of the study was to assess early (aged 0-8) years' education and duties within the context of the Oromo GS and to find out the likely positive and/or negative effects that the roles may have on later life experiences of the children. This age in Ormo GS is termed as Dabballe (see Table 2). More specifically, the study intended to investigate the duties portraying: a) socio-economic, b) cultural, and c) political roles that are associated to the early years life within the Oromo GS. To achieve this objective, the study attempted to answer a question: What duties (portraying socioeconomic, cultural and political roles) are associated to the early years life within the Oromo GS?

\subsection{Methods and Procedures of the Study}

The study employed exclusively qualitative approach. The data for the study were collected by conducting interviews with purposively selected 8 individuals and by reviewing extant literatures available on the area. The data sources were drawn from five colleges at Addis Ababa University, Ethiopia: One from the College of Law and Governance Studies; one from College of Education and Behavioral Studies; three from College of Humanities, Language Studies, Journalism and Communication; two from College of Social Sciences, one from College of Development Studies.

Both sorts of data-obtained from the interviews and reviewing literatures have been brought under pertinent themes- supplementing each other and serving triangulation purposes.

As shown in Table 3 below, coding has been used to protect the identity of the interviewees. In addition, two visits were made to places where children practice modeling desirable deeds and opposing undesirable deeds.

\begin{tabular}{|c|c|}
\hline The Eight Interviewees & Code \\
\hline Interviewee One & Int $_{1}$ \\
\hline Interviewee Two & Int $_{2}$ \\
\hline Interviewee Three & Int $_{13}$ \\
\hline Interviewee Four & Int $_{4}$ \\
\hline Interviewee Five & Int $_{5}$ \\
\hline Interviewee Six & Int $_{6}$ \\
\hline Interviewee Seven & Int $_{7}$ \\
\hline Interviewee Eight & Int $_{8}$ \\
\hline
\end{tabular}

Table 3: Coding of the Interviewees

The coding practice is part of the ethical considerations in the research work. Efforts were made to ensure ethical code in conducting interviews and in reviewing literatures. In the first place, efforts were made to secure interviewees' consent and cooperation. Particularly during the actual interviews, care was taken to maintain the moral and psychological makeup of the subjects as individuals. Other than this, the interviewees' right to privacy was maintained. This was in adherence to a promise statement, which was made on the Interview Guide Questions: "All the information to be obtained from you will be treated with complete confidentiality and will be used only for the research purpose". Moreover, the anonymity of the interviewees was maintained in such a way that information they provided by no means could reveal their identities. Except the researcher (me), another person cannot identify the participants from the information they had 
given me. My involvement as a researcher has been underpinned by the norms of qualitative research that allows for the ethical researcher who is involved with participants, and who affects and is affected by events in the research setting (Noffke \& Somekh, 2009).

In the same vein, conscious efforts were made to ensure that the literatures have been reviewed by acknowledging and referencing all sources used. Overall, utmost possible ethical rules have been considered to ensure that the research is conducted in an ethical manner maintaining consent, respect/moral principle, anonymity, confidentiality, and procedural rigor.

\section{The Results}

Questions pertaining to the duties/roles (portraying socio-economic, cultural and political roles) associated to the early yeas life within the Oromo GS has been presented to the interviewees. Different literatures have also been reviewed related to the issues. The findings, therefore, have been presented hereunder.

\subsection{Social and Cultural Duties/Roles}

As the data from different sources show, children within the GS are motivated to fit into social structure of the Oromo. As $\mathrm{Int}_{1}$ and Int $\mathrm{t}_{5}$ indicate, all clans and family members have responsibilities to culture their children by creating visiting events, ceremonies, caring for them, looking after them, and letting them count genealogy and neighborhood through riddles, folktales, etc.; and encouraging them to play "Hibbo" (riddle), all of which prepare them for the later social responsibilities. In GS, children are seen as having great values, which are celebrated with the hope that each newborn child will someday become a responsible member of the society.

As the data synthesized from different sources, the GS has orientations to enable children:

- learn Problem solving skills, about the world, values, and how to do some activities;

- obtain employment,

- $\quad$ aspire to be a better husband/father or wife/mother,

- read and write letters,

- categorize himself/herself as boy/girl,

- $\quad$ engage in sport, and

- Engage in recreation activities.

Moreover, $\mathrm{Int}_{1}$ and $\mathrm{Int}_{3}$ indicate that problem solving skills of children within the GS develop mainly through riddles and brain teasers. Riddles and brain teasers take place mostly at home. Particularly, riddle is common in all parts of Oromia. After dinner, children form divisions and play it. It has its rules whereby the requester raises and later on is obliged to guide the requested to come closer to the answer. The Oromo encourage their children to practice in their language, Afaan Oromo, riddles like the following:

1. Tell me: elder becomes small, a dry that becomes greater than a wet

Answer: Ear, Horn.

2. I'm tall when I'm young and I'm short when I'm old. Who am I?

Answer: A candle

2. What can run but can't walk?

Answer: A drop of water

4. What goes up and doesn't come back down?

Answer: Your age.

5. I will always come, never arrive today. What am I?

Answer: Tomorrow

Children also learn values like respecting the rights of others including women and children, conservation of environment, peaceful conflict resolution, mutual assistance, and the provision of asylum to seekers (ORCTB, 2015).

As Debesu (2009) and Hussein (2004) indicate, children are prepared for their later roles such as: 1) subtle cultural and economic rights, 2) active participation in the ritual aspect of the Gada generation grade system, and 3) to provide an important service to their society as links between communities and peace negotiators during and after conflicts. They are also, introduced to gender-based division of labor. The practices show that in most cases, daughters are cultured to domestic tasks while men dominate those activities in the public domain (Debesu, 2009). That means for Hussein (2004) Children are introduced to:

...cultural attitudes and practices that reflect gender construction. The first is the differential treatment of boys and girls from the moment of their birth. At birth, parents are asked whether they have a gurbaa (baby son) or intala (baby daughter). Indoctrinating boys into masculinity and girls into femininity is conscientiously practiced, for example, by selecting gender-appropriate clothing and hairstyle. Whereas among the Borana Oromo, boys may not be indoctrinated into masculinity unless they leave their dabbale grade (age 0-8), (this is not the case in others including the Arsi, where the midwives declare the sex of the child, usually by ululating five times for the new baby son and four times for the new baby daughter... (p. 108).

From the visits made as an extension to the interviews and document scrutiny, it has been learnt that girls and boys engage separately and/or together in modeling their future desirable deeds and in opposing undesirable ones as can be seen from Figure 1 below. 


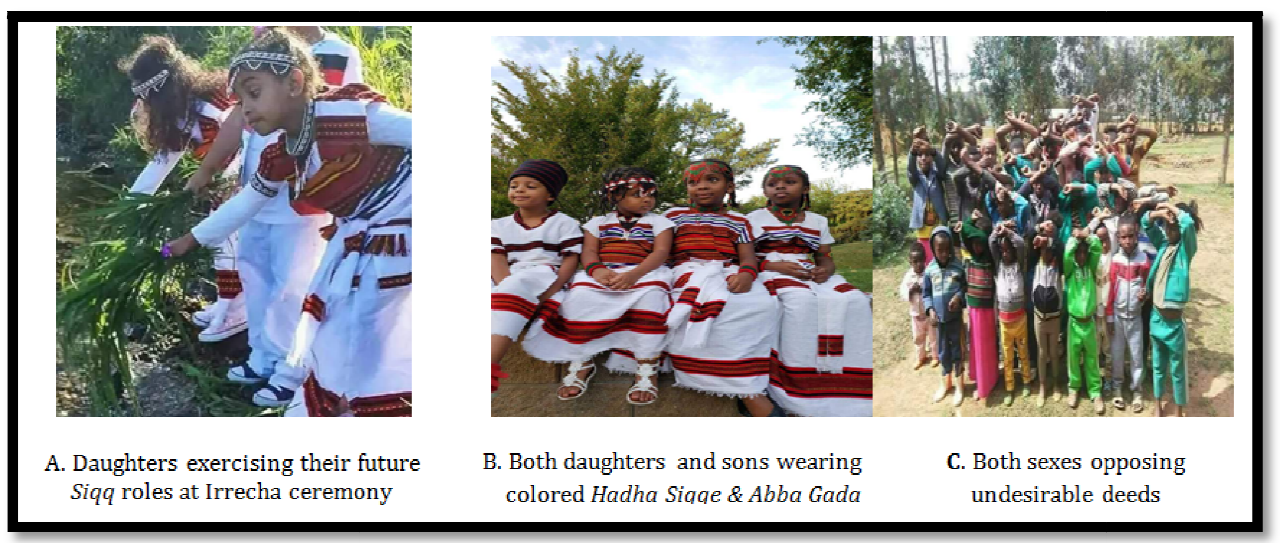

Figure 1: Children Exercising Modeling Desirable Deeds and Opposing Undesirable Ones

As can be seen from Figure 1A children dress Oromo symbolic clothes and participate in cultural and ritual ceremony at a thanks giving even yearly celebrated in Oromia at Oceans, majorly at Hora Arsadi in Bishoftu town 45 kilometers from the capital city of Ethiopia and that of Oromia. Figure $1 \mathrm{~B}$ also depicts that child put on clothes of different colors symbolizing their future roles and participations in Ababa Gada or hadhasiqqe, respectively for males and females.

On the other hand, Figure 1C shows that the visited children were opposing the century long suppression on Oromo and their GS by the Ethiopian rulers with the pretext of nation building since the time the Oromo lost their independence in the $19^{\text {th }}$ Century. Such crossing hands and putting on heads head had been intensified in 2015 by the Oromo youths, named Qeerroo, and resulted in changing the Ethiopian governance system paving ways to bring authentic democracy. Moreover, both girls and boys commonly follow some ceremonies for their later roles. In most cases, whereas sons are prepared for modeling the males' roles, daughters' model that of females' roles.

Furthermore, children are encouraged to engage in any sort of sports. As data from different sources show, children observe and prepare for the popular sports among children and young adults in Oromo society include gugssa (horseback riding), qillee (field hockey), darboo (throwing spears), waldhaansso (wrestling), utaalu (jumping), and swimming. Furthermore, children observe different cultural and recreational engagements that take place during ceremonies such as weddings, holidays, and harvest festivals, during the events that the Oromo eat, drink, sing, dance, and talk together. Jumping, running, swimming, wrestling, and other sports activities are recreation for boys and young adults. Children also observe and listen while Oromo adults sit and chat during weekends, after work, and on holidays. They are also encouraged to model the renowned Oromo athletes, braves, battalions, and famous people (Int ${ }_{1}$ and Int5). Though the case is being changed, male children are taught how to handle weapons for hunting, and to prepare themselves for difficult conditions. This is mainly to model brave Oromo men who used to hunt large animals as a test of manhood.

These all show that within the GS any age set strictly provides its members with values and motives with which they should guide their lives. Particularly, such early engagement of children in social affairs relieves the GS-oriented Oromo identity confusion, which is one typical problem of the technologically sophisticated societies of the current world (Shaffer, 1994; Westen, 1996, Hussein, 2004).

A synthesis from different sources, mainly Baxter (1994) and Debesu (2009 indicate that mainly sons are needed as exemplified hereunder [originally in Afaan Oromo].

When the maize has failed, children and dogs have ruined;

When drought has prolonged, the herds have ruined;

When war has become rampant, the mother of a single son has ruined;

The mother of a single son becomes ill-looking on the day of her death.

Moreover, the Oromo culture their children (boys and girls) to healthy relationships by encouraging them to be friendly to all people, and to express their feelings openly. Children learn early to greet one another by shaking hands; to talk to one another warmly. Ashama? (How are you?), Fayaadhaa? (Are you healthy?), and Maatiinkee atami? (Is your family well?) These are common greeting phrases or questions. The other person answers, Ani fayaadha (I am fine), Maatiinkoosnagaadha (My family is okay), and Atifayaadha? (What about you, are you fine?) (Hussien, 2004).

Moreover, data from almost all the interviewees show that children are cultured through different events including "Tabore" and Walale (children's days). On these days, they ensure their rights, and are respected. Tabore and Walale are annual rituals and events for boys and girls respectively in which they make cultural performances. Beyond these, children are exposed to different kinds of weeduu such as weeduufuudhaa (a marriage song), weeduulolaa (a war song), and weeduuhoiji (a work song). Particularly, girls are exposed to the Oromo women song, called hellee that they use to express their love for their country, children, and husbands. Boys are also exposed to songs through which they at adolescent and beyond age invite girls to friendship and marriage ceremonies by singing hurmiso. Both girls and boys are exposed to men's dhichisaa (a dance to celebrate the marriage ceremony) and to women's shagayoo (singing and dancing) during marriage ceremonies. Moreover, both sexes participate in prayer songs called shubisuu and deedisuu. They are also encouraged to listen to and/or participate in values expressed in geerarsaa or mirisaa (singing), storytelling, poems, proverbs,weeduu, and different cultural activities. Geerarsaa is used to praise good behavior and discourage inappropriate ones. 
As part of the cultural roles, children (both sexes) do not go far away from homes unless otherwise attended by anyone of the families and/or clan members. In such away, children are cultured in respecting their elders and value social responsibility, helping others, bravery, and hard work. Among the Oromo, knowledge of history and culture is admired. Children are, therefore, encouraged to count their family trees through ten generations or more.

Children are also encouraged to engage in different folklore. They are made to acquire the Oromo's belief that WaaqaTokkicha (the one God) created the world, including them. They call this supreme being WaaqaGuuracha (the Black God). Most Oromos still believe that it was this God who created heaven and earth and other living and non-living things. Waaqa also created ayaanaa (spiritual connection), through which he connects himself to his creatures. The Oromo story of creation starts with the element of water, since it was the only element that existed before other elements (Hallpike, 1976; Hinew, 2012). Consequently, children learn from the early age that Uumaa includes everything created by Waaqa, including ayaana, and Saffu, which is a moral and ethical code that the children will be able to differentiate bad from good and wrong from right. The Oromo religious institution, or qalluu, is the center of the Oromo religion. Qalluu leaders traditionally played important religious roles in Oromo society. The past Ethiopian rulers tried to ban the Oromo system of thought by eliminating Oromo cultural experts such as the raagaas (Oromo prophets), the ayaantuus (time reckoners), and oral historians. Above all, children are taught that the original religion sees the human, spiritual, and physical worlds as interconnected, with their existence and functions ruled by Waaqa. Children learn that through each person's ayaanaa (spiritual connection), Waaqa acts in the person's life.

Children are also introduced to Oromo military leaders (heroes and heroines), oral historians who have done something important for the community and famous Oromo figures.

As the same source indicates, in addition to the original Oromo religion (Waaqa), children are also introduced to the Islam, and Christianity (Orthodox and Protestant). Basically, children are exposed to three Oromo concepts explaining the organization and connection of human, spiritual, and physical worlds: ayaanaa, uumaa (nature), and saffu (the ethical and moral code). From the early age, children are introduced to celebrate and respect major holidays including: ireechaa,buttaa, ateetee, as well as Islamic and Christian holidays.

\subsection{Economic Duties /Roles}

As part of economic duties/roles, children in Oromo GS are encouraged tokeep/look after calves, goats, sheep, farms, and home; fetch water, and firewood ( $\operatorname{Int}_{1}$, Int 2 ). The Oromo parents need sons for multiple roles including: for maintaining their lineage, and for economic or social survival. Among the Oromo parents, ilmaa (son) is considered as the prime source of economic and physical support. As an ilmaa, one is supposed to fulfill the socio-economic responsibilities of supporting the parents, particularly in their old age. Hence, the Oromo parents' common prayer is: YaaWaaq, ilmamaleenahinajjeesin! (Waaq, don't destine me to die without a son) (Hussein, 2004).

Practically, children and teenagers participate in agriculture, other activities including crafts and hobbies of making musical instruments such as siinxoo (ulullee), kirar (five-stringed bowl-lyre), masanqo (one-stringed fiddle), and drums.

Though not commonly acknowledged, in some parts of Oromia, children (mainly boys) are also exposed to goldsmiths to specialize in making earrings, necklaces, and other gold objects; and to specialize in making other utensils from horn, pottery, and leather. For instance, children are given horn to make various kinds of bags to hold milk, mugs, spoons, and containers for honey wine; basins, dishes, water jars, and vessels from pottery ( $\operatorname{Int}_{3}$, Int $\mathrm{I}_{5}$ ).

In most cases, Oromo girls bear the largest economic responsibilities including making coffee with ceremonial accessory wearing Oromo cultural cloths and fetching fire woods as can be seen respectively from Figure 2A and 2B below.

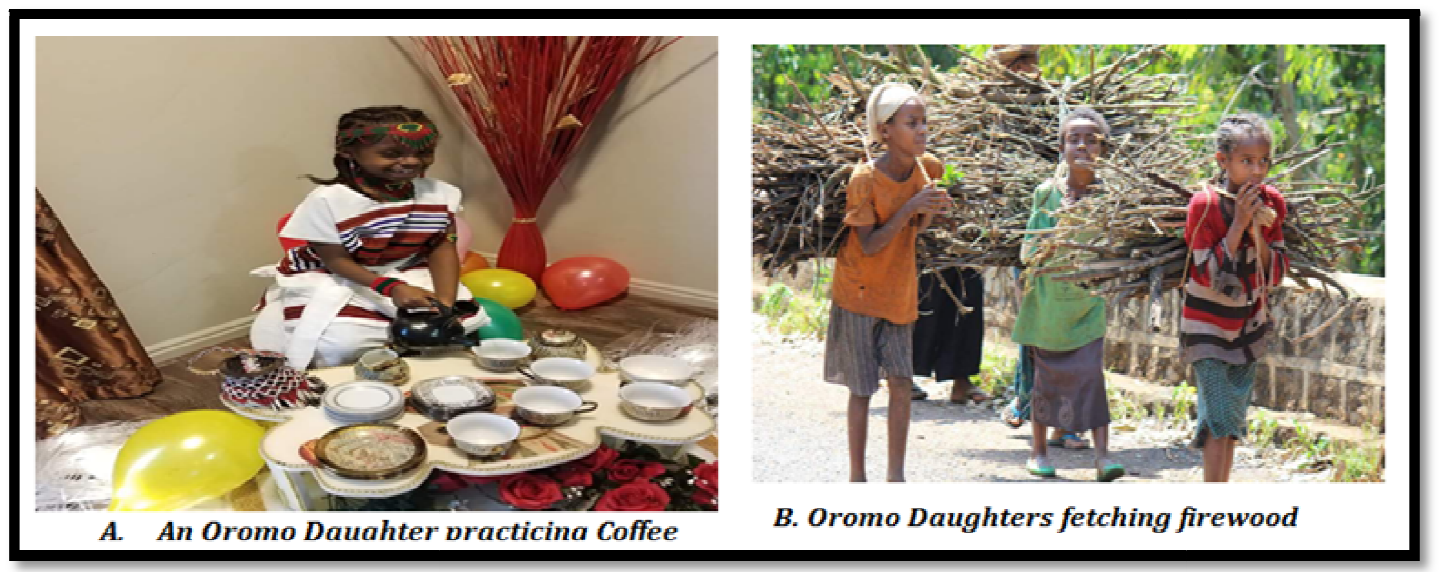

Figure 2: Economic Roles of Oromo Girls

\subsection{Positive Effects of the Roles}

The data obtained from interviewees, literatures, and visits show that the duties (portraying socio-economic, cultural and political roles) have positive effects in many ways. They prepare the children for the world of life, work, and responsibilities that they will face in life at different age levels. The responsibilities, among others, deal with social, economic, cultural, political and religious matters. It, therefore, imbues the children with desirable principles and rules of conduct that situate them rightfully within their future societal roles and responsibilities. 
Requested to tell the positive effects that the roles within the Oromo GS (indicated above) have on later life experiences of children, almost all the interviewees appreciated the positive effects of the roles. Particularly Int , Int $_{5}$, Int 7 and Int 8 indicated that in all the eleven Gada grades and five Gada classes there are freedom and responsibilities through which all children pass. Int 2 added that children practice participatory, achievement and success-based promotion whereby all generations have fair access to exercise and practice political powers. As the same interviewee indicated, there is no suppressed and suppressor group within the Oromo GS.

Inasmuch as the Oromo GS assigns rights, responsibilities, rules and obligations to the members of the Oromo generation in the age-graded manner, every Oromo of specific age-grade is expected to perform a certain function according to specified rules and regulations-demanding learning the customary law and the law of Waaqaa. Children are, therefore, endowed early with the desirable values and principles that the people of Oromo have been putting into practice since long, which eventually serve as a symbol of ensuring unity and solidarity of the people. The values and principles include respecting the rights of all people with special focus on that of children and females', conservation of environment, peaceful conflict resolution, mutual assistance, and the provision of asylum to seekers (ORCTB, 2015; Hallpike, 1976; Hinew, 2012:91-93).

Above all, children in Oromo GS are equipped with the values inherent within the Oromo concept of Reality embedded with instrumental and primordial truth (Dhugaaganamaa) underpinning activities and existences of the people (jiruufijireenyaa), all of which are shaped by the Oromo philosophy: ilaa fi ilaamee. Ilaa fi ilaamee for Yoseph (2016:31) deal respectively with objective knowledge of an entity and one's understanding and interpretation of the entity.

Evidently, therefore, the duties (portraying socio-economic, cultural and political roles) that are associated to the early years life within the Oromo GS shape and mold the children with desirable values, and personalities; and prepare them for life; work; and social, economic, cultural, political and religious responsibilities.

\subsection{Negative Effects of the Roles}

Whereas the majority of the interviewee did not dare say any on the negative effects of the roles within the system, Int 2 , nonetheless, indicated that the roles have aftermath consequences on daughters as they observe that females are mostly involved in serving the political success of males, husbands; not females on their own political competition. Int 7 also indicated that the way the Oromo culture their offspring (with honesty and desirable values) may endanger their kids when they grow up as the environments where they later on work and live are different, particularly now a days. Particularly, whereas the Oromo encourage their kids to be brave naturally-not necessarily depending on artillery, the current world environment is ruled out just by modern artilleries and artificial manipulations. Equally, whereas the Oromo promote in their kids a spirit of inclusiveness and openness, the environment is sometimes the opposite. Similar to this, $\mathrm{Int}_{5}$ indicated that the environment for the Oromo generation who are cultured with Gada values is counter. There is a practice of self-proclaimed pseudo assertions to draw the identity of the Oromo generation without having the mandate and the persona to do so. This shows that it is not the culturing of the Oromo generation that is negatively counter but lack of similar or equivalent desirable values within the society where the children will live and work. Other than this, there are variations in practices and naming of the Gada classes and grades at different places and times. This may dampen the spirits of children to resolutely go for viewing GS as a panacea for the world governance and socio-political chaos. Moreover, Int $_{4}$ andInt 3 hinted that the long-lived GS practices seem static and almost barely align with the dynamism of the world affecting all walks of life.

\section{Conclusions and Implications}

The study had a purpose of investigating early children years' education and duties within the context of the Oromo GS and to find out the likely positive and/or negative effects that the roles may have on later life experiences of the children. Formal and informal observations had shown that various internal and external factors had blurred to precisely tell the duties (portraying socio-economic, cultural and political roles) that are associated to the early yeas life within the Oromo GS calling for investigation, rehabilitations, and reforms. The results from the analysis of the data collected from different sources have shown that children within the GS get matured in all-rounded personality (culturally, socially, economically, administratively, morally, etc.) that endow them with the Oromo concept of reality and the desirable values including cooperativeness, responsiveness, honesty, confidence, bravery, transparency, accountability, fairness, respect for rule of law, transparency, serving, merit-based practices, selflessness and inclusiveness, all of which eventually shape them for the latter social, cultural, economic, political and humanistic roles and responsibilities.

These values are enhanced within the orientations that the GS endow the children by exposing them to problem solving duties, to the later world of work and life, to values, to aspirations to be a better husband/father or wife/mother; to engage in sport, in recreation activities; and to assimilate theme with the environment. From the point of view of cultural duties/roles, children are mannered through different events including "tabore", walale, weedu, hurmiso; shagayoo, decency for saffu, which is a moral and ethical code that the Oromo use to differentiate bad from good and wrong from right.

As their economic duties/roles, children (both sexes) engage in keeping calves, goats, and sheep; and participating in agriculture, and other activities needed for survival. In most cases after the age of 8 years, assignment of the duties is purposively done to shape children differently: males for political administration, and for male specific ritual activities. Females, on the other hand, are prepared for domestic tasks and for influencing the administration through "siqqe" institution, "atete, and other religious and desirable values. They are also prepared for motherhood, routine household chorus, and decency within the society. Duties like boiling coffee, fetching water, collecting firewood, and family care activities are also exclusively assigned for girls after the age of 8 . 
The role assignments within the Oromo GS have majorly positive and to a lesser extent a negative effect on later life experiences of children. The positive effects are pervasive and are inherent in all the eleven Gada grades and five Gada classes that enhance freedom and responsibilities instilling in children desirable values, and personalities endowed with cooperativeness, inclusiveness, responsiveness, open-mindedness, courageousness, participatory, honesty, confidence, responsibility, fairness, moral values and a sense of accountability in their walks of life, work, and responsibilities (social, economic, cultural, political and religious).

In spite of the pervasive positive effects, nonetheless, the gender segregated roles have aftermath consequences. In the first place, girls observe that females are mostly involved in domestic tasks and serving the political success of males, their husbands. Girls observe that females don not compete for Aba Gada positions on their own, rather they engage in consultative and supportive decision-making roles. This leads the girls to view their latter roles are limited to subsidiary, while men dominate those activities in the public domain. Second, whereas the environment in Ethiopia is inundated with self-proclaimed pseudo assertions and pilfering practices that had been mushroomed in Ethiopia by the pretext of nation building, the Oromo concept of reality is founded on its ontological and metaphysical views of: 1) cosmology (uumaa), 2) Supreme being, "undifferentiated being" (Waaqa), and 3) Human ontology (Safuu) - all of which equip the both sexes of the generation with moral accountability (Yoseph, 2016:8). The mismatch due to the unfounded claims and assertions create displacement of the cultured children with some sort of discomfort at work and living environments. Third, variations of the practices and naming of the Gada classes and grades at different places and times may dishearten to resolutely go for viewing the Oromo GS as a panacea for the world governance and socio-political chaos. Fourthly, the long lived economic, cultural, gender, and political roles within the GS seem not dynamic in line with the changing landscape of the world development following the current science and technological detonation.

Overall, girls' observation and conceptions of females' roles; mismatch between the prevailing pseudo claims of knowledge and assertions to draw the Oromo generation, and the Oromo's culturing of their offspring with their concept of reality and values; variations of the practices and naming of the Gada classes and grades; and the almost latent state of the GS vis-à-vis the dynamism of the world imply the need for reform within the GS in line with the demands of the $21^{\text {st }}$ century. There is also a need to open a space for females to hold political and/or administrative leadership positions on their own beyond their consultative and supportive decision-making roles so that girl's model that line.

Relatively and cumulatively, nonetheless, the early years of education in Oromo GS is founded on a common sense of purpose and cooperativeness rather than competitiveness approach. The fact that Children (of both sexes) within the Oromo GS are imbued with desirable values, and principles including cooperativeness, inclusiveness, responsiveness, open-mindedness, participatory, honesty, courageousness, confidence, responsibility, fairness, and a sense of accountability- bestow in them appropriate personalities needed in the 21st century. They, can therefore, fit into local, regional, national, and global cultures of work and life.

\section{References}

i. ArdaaJilaa. Ardaajilaatarreeluugoo Oromoo Karrayyuu, 2009. (Retrieved on 2 March 2017 from http://ardajila.com/?page_id=247)

ii. Baxter, P.T.W; Jan Hulina; \& Alessandro Triulzi. Eds. Being and becoming Oromo: Historical and Anthropological Enquiries. USA: The Red Sea Press, Inc, 1996.

iii. Baxter, P.T.W. "The creation and constitution of Oromo nationality", in Fukui \&Markakis, eds. Ethnicity and Conflict in the Horn of Africa, pp. 167-186. London, James Currey, 1994.

iv. Bokkuu, Dirribii. IlaalchaOromoo: Barrooamantaa, sirnaBulchiinsaa fi seenaaOromoo. Finfinnee: D.G Printing \& Publishing Enterprise, 2009.

v. Bulcha, M. The Survival and reconstruction of Oromo. In (P.T.W. Baxter, J. Hultin\& A. Triulizi, eds.) Being and Becoming Oromo: Historical and Anthropological Enquiry, pp. 48-66. The Red Sea press, Asmara, 1996.

vi. Debesu, Dejene N. "Gender and culture in southern Ethiopia: an ethnographic analysis of guji-Oromo women's customary rights." African Study Monographs vol 30, no.1 (2009), 15-36.

vii. Jaarraa, A. \&Saaddoo, M. SeenaaOromoo fi Maddawalaabuu: Iccitiijaarraa 16ffaeesso. Finfinne: Natco printing, 2011.

viii. Jalata, Aseffa "The struggle for knowledge: The case of emergent Oromo studies." African Studies Review, vol. 39, no. 2 (1996), 95-123.

ix. Hallpike, C. R. "The Origins of the Borana GS: A Discussion of Gada: Three Approaches to the Study of African Society by AsmaromLegesse." Journal of the International African Institute, Vol. 46, No. 1, (1976), 48-56

x. Hassen, M. The Oromo of Ethiopia: A History, 1570-1860. Trenton: The Red Sea Press, 1990.

xi. Hassen, M. The development of Oromo Nationalism. In (P.T.W. Baxter, J. Hultin\& A. Triulizi, eds.) Being and Becoming Oromo: Historical and Anthropological Enquiry, pp.167-180. The Red Sea press, Asmara, 1996.

xii. Hinew, Dereje. "History of Oromo Social Organization: Gadaa Grades based roles and Responsibilities." Science, Technology \& Arts Research journal, Vol. 1, no.3 (2012) 88-96.

xiii. Hussein, Jeylan. "A cultural representation of women in the Oromo society." African Study Monographs, vol. 25, no. 3(2004) 103-147.

xiv. Legesse, Asmarom. Gada: Three Approaches to the Study of African Society. New York: The Free Press, 1973.

xv. Legesse, Asmarom. Oromo Democracy: An Indigenous African Political system. The Red Sea Press, 2001.

xvi. Noffke, S. and Somekh, B [eds]. Educational Action Research. London: SAGE Publications Ltd., 2009. 
xvii. Oromia Regional State Culture and Tourism Bureau [ORCTB]. Petition by the Oromo people for the inscription of the GSon the Representative List of

Intangible Cultural Heritage of Humanity, Ref. No. Dh.A. G 13-1/2599,

Date: 13/03/2015, 2015.

xviii. ORCTB. The Gada system; full Democratic politics of Oromo; 71st BoranaBalli Hand overing Day February 2009/20017: The Gada of Kura Jarso, 2017 (retrieved on 7 October 2018 from https://www.oromiatourism.gov.et/attachments/.../13/The\%20\%20Gada\%20system.pdf)

xix. Shaffer, D.R. Social and Personality Development. 3rd ed. California: Brooks/Cole Publishing, Pacific Grove, 1994.

xx. Unpo. Unrepresented Nations and Peoples Organization, 2016 (retrieved on 2 March 217 from http://unpo.org/)

xxi. Westen, D. Psychology: Mind, Brain and Culture. New York: John Wiley \& Sons, 1996.

xxii. Yoseph M, Baba. The Oromo Concept of Reality: Epistemological Approach. Addis Ababa: Africa Printing Press, 2016. 